\title{
Gene polymorphism of interleukin 1 and 8 in chronic gastritis patients infected with Helicobacter pylori
}

\author{
Agostinho Caleman Neto ${ }^{1}$, Lucas T Rasmussen², Roger W de Labio ${ }^{1}$, Valdeir F de Queiroz ${ }^{3}$, Marília de AC Smith ${ }^{4}$, \\ Gustavo A Viani ${ }^{5}$ and Spencer LM Payão $0^{1,2,6^{*}}$
}

\begin{abstract}
Background: Epidemiological investigations have indicated that Helicobacter pylori induces inflammation in the gastric mucosa regulated by several interleukins. The genes $I L 1 B$ and $I L 8$ are suggested as key factors in determining the risk of gastritis. The aim of this paper was to evaluate the association of gene polymorphism of interleukin-1 and interleukin-8 with chronic gastrits in H. pylori infected patients. A total of 60 patients underwent endoscopic procedure. Biopsy samples were collected for urease test, histopathological and molecular exams. The DNA of theses samples was extracted for detection of $\mathrm{H}$. pylori and analysis of the genes mentioned above. Patients with gastritis had a higher frequency of $\mathrm{H}$. pylori-positive samples.
\end{abstract}

Results: H. pylori was detected in 30/60 patients (50\%) by PCR. As for polymorphism of interleukin $8(-251)$ gene we observed a statistical difference when analyzed TA $(p=0.039)$ and $T(p=0.047)$ genotypes. In the IL1B31 there was a statistical difference in $T(p=0.01)$ genotype and in the IL1B-511 there wasn't any statistical difference.

Conclusion: Our results suggest a strong correlation between the presence of chronic gastritis and infection by $\mathrm{H}$. pylori and that IL1B-31TT and IL8-251TT genotypes appear to act as protective factors against $H$. pylori infection while IL8-251TA genotype may comprise a risk factor for infection with this bacterium.

Keywords: Helicobacter pylori, Polymorphism, Interleukin

\section{Background}

Helicobacter pylori is a gram-negative bacterium that colonizes the gastric antrum and/or the body of the human stomach, causing complications such as gastritis, gastric and duodenal ulcer and gastric malignancies [1,2]. H. pylori is present in approximately half of the world population [3]. Numerous studies have shown a significant relationship between the bacteria and the risk of gastritis [4,5]. Atherton [6] reported that the development of gastric diseases is influenced by the degree of virulence of the H. pylori strain, the host genetic susceptibility and environmental cofactors.

Some virulence factors, such as vacA and cagA genes, were studied since they could play an important role in

\footnotetext{
* Correspondence: slmpayao@famema.br

'Department of Genetics, FAMEMA Blood Center, Marília Medical School (FAMEMA), Marília, São Paulo State, Brazil

${ }^{2}$ Sacred Heart University (USC), Bauru, São Paulo State, Brazil

Full list of author information is available at the end of the article
}

the pathogenesis of infection with $H$. pylorii. The vacA gene, present in all strains, covers two different regions, the "s" region (s1 and s2) and the " $\mathrm{m}$ " region ( $\mathrm{m} 1$ and $\mathrm{m} 2$ ) [7]. Another relevant marker of pathogenicity is the cagA gene, present in about $60-70 \%$ of the $H$. pylori strains. Infection with $H$. pylori cagA + strains have been associated with a greater degree of inflammation of the gastric mucosa and severe atrophic gastritis. Therefore, it has been suggested to play an important role in the development of gastric carcinoma $[7,8]$.

Chronic infection with $H$. pylori results in inflammation of the gastric mucosa, which induces the expression of proinflammatory cytokines such as interleukins, tumor necrosis factor (alpha), and interferon [9].

Several genetic polymorphisms related to inflammatory cytotoxins have been studied and associated with an increase in the synthesis of these interleukins. The polymorphisms of some interleukins are important in cancer 
susceptibility [10,11]. H. pylori may indirectly stimulate the activation of an inflammatory cascade of cytotoxins, which induces the production of chemokines for neutrophils and mononuclear cells, as well as interleukins IL8 and IL1, leading to a response with an inflammatory infiltrate and development of chronic gastritis [12]. The IL8 gene has been described as having a polymorphism of an $\mathrm{A} / \mathrm{T}$ base pair in the promoting region $(-251)$ which is associated with an increase in the synthesis of interleukin by gastric epithelial cells $[13,14]$.

The presence of $-31 C C$ or $-511 T T$ genotypes of interleukin $1 B$ may render patients at increased risk of developing gastric atrophy and hypochlorhydria by infection of $H$. pylori, which can also lead to a two- to threefold increased risk of malignancy compared to the presence of less inflammatory genotypes $[15,16]$. Cytokine $I L 1 B$ $31 C C /-511 T T$ gene polymorphisms have been shown to be related to gastric cancer and chronic gastritis development in patients infected by H. pylori. [16,17]. Therefore, the aim of this paper was to evaluate association of gene polymorphisms of interleukin 1 and 8 with chronic gastrits in $H$. pylori infected patients.

\section{Methods}

\section{Patients and samples}

Thirty adults (mean age 49.5 years old) that tested positive for H. pylori infection and had recurrent abdominal pain were included in the present study. Control group comprised 30 individuals in the same age group. All subjects were recruited from the Endoscopy Unit of Marilia Medical School, SP, Brazil. Demographics of these patients were obtained from medical records. Three biopsy samples from each patient were collected from the gastric antrum in order to be submitted for histopathological examination, rapid urease test and DNA extraction.

All patients or legal guardians were informed about the objectives and the research protocol of the present study. They all signed an informed consent form approved by the Research Ethics Committee of Marília Medical School (protocol n. 1119/11).

\section{DNA extraction and $H$. pylori detection}

DNA was extracted from the gastric biopsies using the QIAamp ${ }^{\circ}$ tissue kit (Qiagen, Germany) according to the manufacturer's instructions. For the detection of $H$. pylori the PCR technique was employed, which amplifies a fragment of $150 \mathrm{bp}$ from the 16S rRNA of H. pylori [18]. PCR conditions comprised 40 cycles of amplification, each cycle consisted of 45 seconds of denaturation at $94^{\circ} \mathrm{C}, 45$ seconds of annealing at $59^{\circ} \mathrm{C}$ and 45 seconds extension at $72^{\circ} \mathrm{C}$. In each experiment, positive (strain 26695) and negative (water) controls were included.

\section{Histopathology and rapid urease test}

The fragments were fixed with $10 \%$ formalin and stained by hematoxylin-eosin and Giemsa. Microscopic examination defined the degree of involvement of the gastric mucosa and presence of Helicobacter pylori.

An antral biopsy from each patient was incubated in premade broth (TUPF; Laborclin, Brazil) for the urease test immediately after collection. The test was considered positive when the color of the solution changed from yellow to orange, pink, or purple within four hours of incubation at $25^{\circ} \mathrm{C}$.

\section{Interleukin- $1 \beta$ genotyping}

In order to characterize $I L 1 \beta(-31,-511)$ gene polymorphism, restriction fragment length polymorphism (RFLP) was employed. Similarly, polymorphism of the promoting region $(-511)$ in the $I L 1 \beta$ gene was identified using PCR primers under the conditions described by Wilkinson et al. [19]. AvaI enzyme was used to digest the PCR products at $37^{\circ} \mathrm{C}$ overnight. Electrophoresis in 3\% agarose gel stained with ethidium bromide showed the following bands: CC (80 and $109 \mathrm{bp})$, CT (80, 109 and $189 \mathrm{bp})$ and TT (189 bp).

To the promoting region $(-31)$ of the IL1 $\beta$ gene the AluI enzyme was used for digestion at $37^{\circ} \mathrm{C}$ overnight [15]. The following bands, separated by electrophoresis in $3 \%$ agarose gel stained with ethidium bromide, were observed: CC (240 bp); CT ( 98, 137 and $240 \mathrm{bp)}$ and TT (98 and $137 \mathrm{bp)} \mathrm{[20].}$

\section{Interleukin-8 genotyping}

IL8 (-251) gene polymorphisms were characterized through RFLP as previously described [21]. The PCR product, a 349-bp fragment, was digested by MunI restriction enzyme (MBI Fermentas, Canada) overnight at $37^{\circ} \mathrm{C}$ and then separated by electrophoresis in $3 \%$ agarose gel stained with ethidium bromide. The digestion fragments had $349 \mathrm{bp}$ with TT genotype, 202 and $147 \mathrm{bp}$ with AA genotype and 349, 202 and $147 \mathrm{bp}$ with TA genotype.

\section{Results}

Helicobacter pylori was detected in 30 of the 60 patients (50\%) by PCR whereas the urease test detected the bacterium in 21 patients (35\%) (Table 1). All the samples in which the histology and urease test demonstrated the presence of $H$. pylori were also positive by PCR, showing a sensitivity of $65 \%$ and specificity of $100 \%$ by PCR and sensitivity of $43.5 \%$ and specificity of $92.9 \%$ by rapid urease test. The histopathological analysis revealed the presence of chronic gastritis in 46 subjects (76.6\%).

In relation to the distribution of IL1B-511 polymorphisms, no significant difference was observed in genotype distribution among patients infected with $H$. pylori 
Table 1 PCR and urease test detection for $H$. pylori in patients with chronic gastritis and negative control group

\begin{tabular}{lccc}
\hline & \multicolumn{2}{c}{ Chronic gastritis } & \\
\cline { 2 - 3 } PCR & Negative (\%) & Positive (\%) & Total \\
\hline Positive & $0(0)$ & $30(100)^{*}$ & 30 \\
Negative & $14(46.7)$ & $16(53.3)$ & 30 \\
\hline Urease & Negative & Positive & Total \\
\hline Positive & $1(4.8)$ & $20(95.2)^{*}$ & 21 \\
Negative & $13(33.3)$ & $26(66.7)$ & 39 \\
\hline
\end{tabular}

*Statistical difference was observed.

and the control group. However, when polymorphism distribution of genotype $I L 1 B$-31 was analyzed, a significant difference was found. Frequency of TT genotype was lower in $H$. pylori-infected patients $(6.7 \%)$ when compared with the non-infected group $(33.3 \%, \mathrm{p}=0.01)$.

When IL8-251 polymorphisms were analyzed, a significant variation was found. The distribution of TA genotype was higher in $H$. pylori-infected patients $(63.3 \%)$ than in the control group (36.7\%, $\mathrm{p}=0.039)$ whereas the frequency of TT genotype was higher in controls (43.3\%) than in infected patients $(20 \%, \mathrm{p}=0.047)$. These results of polymorphisms are displayed in Table 2.

\section{Discussion}

In the present study, we analyzed gene polymorphisms of $I L 8$ and $I L 1 B$ together with $H$. pylori infection in groups of adult patients from Marília, SP, Brazil. Recently, researchers have been focusing their attention on the possible connection between human gene polymorphisms and H. pylori infection. From the investigated genes, it is important to emphasize the role of proinflammatory IL-1 polymorphism (IL1B-511 T/-31C), demonstrated in experiments conducted by El-Omar et al. [15].

In the Japanese population, $I L 1 B-511 C>C$ polymorphism was dominant among patients with advanced atrophic chronic gastritis, whereas IL1B-511 $T>T+T>C$ polymorphism was more frequent in the Chinese population. In addition, no differences were found in the frequency of occurrence of $\mathrm{C}$ and $\mathrm{T}$ alleles in Tai and Vietnamese populations [22]. Regarding the Chinese case, interesting observations have shown that the IL1B$511 T T$ genotype disclosed an association between peptic disease and H. pylori [23]. Santos et al. [24] found that in the Brazilian population, IL1 $\beta-511 C C$ and CT gene polymorphisms were associated with chronic gastritis and gastric cancer development in $H$. pylori-infected individuals. Our results of patients non-infected and infected with $H$. pylori revealed no association with IL1B-511 polymorphisms.

The Chinese research also found that IL1B-31CC genotype was more frequent in carcinoma patients than in the control group in northern China (a region characterized by high incidence of gastric carcinoma), whereas in southern China (a region with low gastric carcinoma incidence) it was more frequent in controls than in cancer patients [23]. This indicates that the $\mathrm{T}$ allele could act as a proinflammatory allele in genotype $I L 1 B-31 \mathrm{~T}$ and both genotypes may constitute independent gastric carcinoma risk factors. These hypotheses were corroborated by investigations carried out in Korea, which indicated the importance of $H$. pylori infection and presence of $I L 1 B-31 T$ and $I L 1 B-$ $511 C$ polymorphism for the increase of $I L 1 B$ production by the gastric mucosa [25]. Our results suggest that the genotype $I L 1 B-31 T T$ emerge as a possible protector factor against $H$. pylori. Similar results were found in Turkish patients [26].

Cheng et al. [27] found no association of polymorphisms of IL8-251 T >A with increased risk of gastritis in Thai patients, as well as Fabris et al. [28] who did not find any significant association between $I L-8-251 T>A$ polymorphism and $H$. pylori infection in Brazilian patients. However, some studies reported controversial results. Hofner et al. [29] described an association between IL8 (TA) genotype and risk for gastritis or duodenal ulcers in patients infected with $H$. pylori. Ohyauchi et al. [11] and Taguchi et al. [13] observed that the AA genotype confers higher risk for atrophic gastritis compared to the TT genotype in patients with $H$. pylori. These authors also associated TA and AA genotypes with augmented levels of IL8 and higher degree of neutrophil infiltration when compared with the TT genotype.

In the present study, we found a significant difference between TA and TT genotypes of IL 8 and the presence of $H$. pylori. However, such relation was not true for the AA genotype, which suggests that the presence of TA genotype may be a risk factor $H$. pylori infection whereas TT genotype may act as a protector factor against $H$.

Table 2 Genotype distribution of single nucleotide polymorphisms of IL1B and IL8 in Brazilian adult patients according to PCR results for $H$. pylori infection

\begin{tabular}{|c|c|c|c|c|c|c|c|c|c|c|c|c|}
\hline \multirow[t]{2}{*}{ PCR } & \multicolumn{3}{|c|}{ IL1B-31 } & \multirow[b]{2}{*}{ Total } & \multicolumn{3}{|c|}{ IL1B-511 } & \multirow[b]{2}{*}{ Total } & \multicolumn{3}{|c|}{ IL8-251 } & \multirow[b]{2}{*}{ Total } \\
\hline & CC (\%) & TC (\%) & TT (\%)* & & CC (\%) & TC (\%) & $\mathrm{TT}(\%)$ & & AA (\%) & TA $(\%)^{*}$ & TT $(\%)^{*}$ & \\
\hline Pos. & $10(33.3)$ & $18(60)$ & $2(6.7)$ & 30 & $11(36.7)$ & $13(43.3)$ & $6(20)$ & 30 & $5(16.7)$ & 19 (63.3) & $6(20)$ & 30 \\
\hline Neg. & $5(16.7)$ & $15(50)$ & $10(33.3)$ & 30 & 10 (33.3) & $16(53.3)$ & $4(13.4)$ & 30 & $6(20)$ & $11(36.7)$ & $13(43.3)$ & 30 \\
\hline
\end{tabular}

*Statistical difference was observed. 
pylori. In most of the eastern population the presence of the A allele in the promoting region $(-251)$ of the $I L 8$ gene was related to an increased risk of stomach malignancy $[11,13,30]$. According to some studies, production of IL8 is augmented by the presence of A allele, and the quality and intensity of inflammatory responses produced by the host can be altered after exposure to H. pylori $[13,14,30]$.

The discrepancy among IL 8 genotypes may be related to genetic differences in populations and sample sizes. However, the frequency of $I L-8-251 T A$ genotype was found to be different among ethnic groups as reported in the single nucleotide polymorphism database (http:// www.ncbi.nlm.nih.gov/SNP/snp_ref.cgi?rs=4073).

Polymorphisms of $I L 8$ are biologically important in the pathogenesis of gastric diseases. Therefore, further studies in different populations are required, since these polymorphisms in some demographic regions appear to be essential in the development of gastric diseases. Our results showed a significant role of polymorphisms of genes ILI and IL8 in relation to the infection by $H$. pylori and the development of gastric mucosa inflammation. It is necessary to bear in mind that gene polymorphisms of other cytokines and other genetic factors may exert a synergistic action in the development of such changes related to H. pylori.

\section{Conclusion}

In summary, the current results suggest a strong correlation between the presence of chronic gastritis and infection by $H$. pylori. In addition, the IL1B-31TT and IL8-251 $T T$ genotypes seem to act as protective factors against H. pylori infection while IL8-251TA genotype may be a risk factor for infection with this bacterium. These polymorphisms are biologically important in the pathogenesis of gastric diseases and require more studies in different populations, since they appear to be an important variable in the development of gastric diseases in some individuals exposed to H. pylori.

\section{Ethics committee approval}

Patients or legal guardians were informed about the objectives and the research protocol of the present study. They all signed an informed consent form approved by the Research Ethics Committee of Marília Medical School (protocol n. 1119/11).

\section{Competing interests}

The authors declare that they have no competing interests.

\section{Authors' contributions}

All authors read and approved the final manuscript. ACN carried out the sample collection, DNA extraction and molecular analysis. RWL, LTR, GV, VFQ, MACS, SLMP and ACN participated in the study design, performed the statistical analysis and provided technical support and scientific discussions.
SLMP and ACN designed of the study, coordinated the research and helped to draft the manuscript.

\section{Acknowledgments}

The authors would like to thank the State of São Paulo Research Foundation (FAPESP), grant n. 0915857-9) and Marília Medical School for their funding of this research.

\section{Author details}

'Department of Genetics, FAMEMA Blood Center, Marília Medical School (FAMEMA), Marília, São Paulo State, Brazil. ${ }^{2}$ Sacred Heart University (USC), Bauru, São Paulo State, Brazil. ${ }^{3}$ Department of Digestive System Surgery, Marília Medical School (FAMEMA), Marília, São Paulo State, Brazil.

${ }^{4}$ Department of Morphology, Federal University of São Paulo (UNIFESP), São Paulo, São Paulo State, Brazil. ${ }^{5}$ Department of Radiotherapy and Oncology, Marília Medical School (FAMEMA), Marília, São Paulo State, Brazil. '́Laboratório de Genética, Hemocentro, FAMEMA, Rua Lourival Freire, 240, Bairro Fragata, Marília, São Paulo CEP 17519-050, Brazil.

Received: 7 January 2014 Accepted: 2 April 2014

Published: 23 April 2014

\section{References}

1. Marshall BJ: Helicobacter pylori. Am J Gastroenterol 1994, 89(8):S116-S128.

2. Liu YE, Gong YH, Sun LP, Xu Q, Yuan Y: The relationship between $H$. pylori virulence genotypes and gastric diseases. Pol J Microbiol 2012, 61(2):147-150.

3. Mitchell HM: The epidemiology of Helicobacter pylori. Curr Top Microbiol Immunol 1999, 241:11-30.

4. Kignel S, de Almeida PF, André EA, Alves Mayer MP, Birman EG: Occurrence of Helicobacter pylori in dental plaque and saliva of dyspeptic patients. Oral Dis 2005, 11(1):17-21.

5. De Vries AC, Kuipers EJ: Review article: Helicobacter pylori eradication for the prevention of gastric cancer. Aliment Pharmacol Ther 2007, 26(Suppl 2):25-35.

6. Atherton JC: H. pylori virulence factors. Br Med Bull 1998, 54(1):105-120.

7. Karlsson A, Ryberg A, Dehnoei MN, Borch K, Monstein HJ: Association between cagA and vacA genotypes and pathogenesis in a Helicobacter pylori infected population from South-eastern Sweden. BMC Microbiol 2012, 12:129. doi:10.1186/1471-2180-12-129.

8. Rasmussen LT, de Labio RW, Neto AC, Silva LC, Queiroz VF, Smith MAC, Payão SLM: Detection of Helicobacter pylori in gastric biopsies, saliva and dental plaques of dyspeptic patients from Marília, São Paulo, Brazil: presence of vacA and cagA genes. J Venom Anim Toxins Incl Trop Dis 2012, 18(2):8 [http://www.scielo.br/scielo.php?pid=\$0074-02762010000300015\& script=sci_arttext]

9. Misiewicz Jj: Current insights in the pathogenesis of Helicobacter pylori infection. Eur J Gastroenterol Hepatol 1995, 7:701-703.

10. Crabtree JE, Lindley IJ: Mucosal interleukin-8 and Helicobacter pyloriassociated gastroduodenal disease. Eur J Gastroenterol Hepatol 1994, 6(Suppl 1):S33-S38.

11. Ohyauchi M, Imatani A, Yonechi M, Asano N, Miura A, lijima K, Koike T, Sekine $H$, Ohara S, Shimosegawa T: The polymorphism interleukin 8-251 $\mathrm{A} / \mathrm{T}$ influences the susceptibility of Helicobacter pylori related gastric diseases in the Japanese population. Gut 2005, 54(3):330-335. doi:10.1136/gut.2003.033050.

12. Israel DA, Salama N, Krishna U, Rieger UM, Atherton JC, Falkow S, Peek RM Jr: Helicobacter pylori genetic diversity within the gastric niche of a single human host. Proc Natl Acad Sci U S A 2001, 98(25):14625-14630.

13. Taguchi A, Ohmiya N, Shirai K, Mabuchi N, Itoh A, Hirooka Y, Niwa Y, Goto $\mathrm{H}$ : Interleukin-8 promoter polymorphism increases the risk of atrophic gastritis and gastric cancer in Japan. Cancer Epidemiol Biomarkers Prev 2005, 14(11 Pt):2487-2493.

14. Vinagre RMDF, Corvelo TCO, Arnaud VC, Leite ACK, Barile KAS, Martins LC: Determination of strains of Helicobacter pylori and of polymorphism in the interleukin-8 gene in patients with stomach cancer. Arq Gastroenterol 2011, 48(1):46-51.

15. El-Omar EM, Carrington M, Chow WH, McColl KE, Bream JH, Young HA, Herrera J, Lissowska J, Yuan CC, Rothman N, Lanyon G, Martin M, Fraumeni JF Jr, Rabkin CS: Interleukin-1 polymorphisms associated with increased risk of gastric cancer. Nature 2000, 404(6776):398-402. 
16. Wang SY, Shen XY, Wu CY, Pan F, Shen YY, Sheng HH, Chen XM, Gao HJ: Analysis of whole genomic expression profiles of Helicobacter pylori related chronic atrophic gastritis with IL-1B-31CC/-511TT genotypes. J Dig Dis 2009, 10(2):99-106.

17. Sicinschi LA, Lopez-Carrillo L, Camargo MC, Correa P, Sierra RA, Henry RR, Chen J, Zabaleta J, Piazuelo MB, Schneider BG: Gastric cancer risk in a Mexican population: role of Helicobacter pylori cagA positive infection and polymorphisms in interleukin-1 and -10 genes. Int J Cancer 2006, 118(3):649-657.

18. Scholte GH, van Doorn LJ, Quint WG, Lindeman J: Polymerase chain reaction for the detection of Helicobacter pylori in formaldehyde-sublimate fixed, paraffin-embedded gastric biopsies. Diagn Mol Pathol 1997, 6(4):238-243.

19. Wilkinson RJ, Patel P, Llewelyn M, Hirsch CS, Pasvol G, Snounou G, Davidson RN, Toossi Z: Influence of polymorphism in the genes for the interleukin (IL)-1 receptor antagonist and IL-1beta on tuberculosis. J Exp Med 1999, 189(12):1863-1874.

20. Barbosa HPM, Martins LC, dos Santos SEB, Demarchki S, Assumpção MB, Aragão CD, Corvello TCO: Interleukin-1 and TNF-a polymorphisms and Helicobacter pylori in a Brazilian Amazon population. World J Gastroenterol 2009, 15(12):1467-1471.

21. Hamajima N, Katsuda N, Matsuo K, Saito T, Hirose K, Inoue M, Zaki TT, Tajima K, Tominaga S: High anti-Helicobacter pylori antibody seropositivity associated with the combination of IL-8-251TT and IL-10-819TT genotypes. Helicobacter 2003, 8(2):105-110.

22. Matsukura N, Yamada S, Kato S, Tomtitchong P, Tajiri T, Miki M, Matsuhisa T, Yamada N: Genetic differences in interleukin-1 betapolymorphisms among four Asian populations: an analysis of the Asian paradox between H. pylori infection and gastric cancer incidence. J Exp Clin Cancer Res 2003, 22(1):47-55.

23. Zeng ZR, Hu PJ, Hu S, Pang RP, Chen MH, Ng M, Sung JJ: Association of interleukin $1 \mathrm{~B}$ gene polymorphism and gastric cancers in high and low prevalence regions in China. Gut 2003, 52(12):1684-1689.

24. Santos JC, Ladeira MSP, Pedrazzoli J Jr, Ribeiro ML: Relationship of IL-1 and TNF-a polymorphisms with Helicobacter pylori in gastric diseases in a Brazilian population. Braz J Med Biol Res 2012, 45(9):811-817.

25. Chang YW, Jang JY, Kim NH, Lee JW, Lee HJ, Jung WW, Dong SH, Kim HJ, Kim BH, Lee Jl, Chang R: Interleukin-1B (IL-1B) polymorphisms and gastric mucosal levels of IL-1beta cytokine in Korean patients with gastric cancer. Int J Cancer 2005, 114(3):465-471.

26. Erzin Y, Koksal V, Altun S, Dobrucali A, Aslan M, Erdamar S, Goksel S, Dirican A, Kocazeybek B: Role of host interleukin 1beta gene (IL-1B) and interleukin 1 receptor antagonist gene (IL-1RN) polymorphisms in clinical outcomes in Helicobacter pylori-positive Turkish patients with dyspepsia. J Gastroenterol 2008, 43(9):705-710.

27. Cheng HH, Chang CS, Wang HJ, Wang WC: Interleukin-1 beta and -10 polymorphisms influence erosive reflux esophagitis and gastritis in Taiwanese patients. J Gastroenterol Hepatol 2010, 25(8):1443-1451.

28. Fabris RC, Rasmussen LT, Neto AC, de Labio RW, Orcini W, Ximenez JPB, Franzolin S, Payao SLM: Polimorfismo da Interleucina-8-251 T > A e Helicobacter pylori. Arq Catar Med 2012, 40(3):25-29.

29. Hofner P, Gyulai Z, Kiss ZF, Tiszai A, Tiszlavicz L, Tóth G, Szõke D, Molnár B, Lonovics J, Tulassay Z, Mándi Y: Genetic polymorphisms of NOD1 and IL-8, but not polymorphisms of TLR4 genes, are associated with Helicobacter pylori-induced duodenal ulcer and gastritis. Helicobacter 2007, 12(2):124-131.

30. Ye BD, Kim SG, Park JH, Kim JS, Jung HC, Song IS: The interleukin-8-251 A allele is associated with increased risk of noncardia gastric adenocarcinoma in Helicobacter pylori-infected Koreans. J Clin Gastroenterol 2009, 43(3):233-239.

doi:10.1186/1678-9199-20-17

Cite this article as: Caleman Neto et al: Gene polymorphism of interleukin 1 and 8 in chronic gastritis patients infected with Helicobacter pylori. Journal of Venomous Animals and Toxins including Tropical Diseases 2014 20:17.

\section{Submit your next manuscript to BioMed Central and take full advantage of:}

- Convenient online submission

- Thorough peer review

- No space constraints or color figure charges

- Immediate publication on acceptance

- Inclusion in PubMed, CAS, Scopus and Google Scholar

- Research which is freely available for redistribution

Submit your manuscript at www.biomedcentral.com/submit
() Biomed Central 